\title{
Removal of Macro-pollutants in Oily Wastewater Obtained from Soil Remediation Plant Using Electro-oxidation Process
}

Mehdi Zolfaghari a, Patrick Drogui a*, Jean François Blais ${ }^{\text {a }}$

a Institut National de la Recherche Scientifique, Eau, Terre et Environnement (INRS-ETE), Université du Québec, 490 rue de la Couronne, Québec, QC, Canada, G1K 9A9.

* Corresponding author

Author email: mehdi.zolfaghari@ete.inrs.ca

patrick.drogui@ete.inrs.ca

jean-francois.blais@inrs.ca

September 2017 


\begin{abstract}
Electro-oxidation process by Niobium boron-doped diamond (Nb/BDD) electrode was used to treat non-biodegradable oily wastewater provided from soil leachateed contaminated by hydrocarbons. Firstly, the diffusion current limit and mass transfer coefficient was experimentally measured $\left(7.1 \mathrm{~mA} \mathrm{~cm}^{-2}\right.$ and $14.7 \mu \mathrm{m} \mathrm{s}^{-1}$, respectively), in order to understand minimum applied current density. Later on, the oxidation kinetic model of each pollutant was investigated in different current densities ranged between 3.8 to $61.5 \mathrm{~mA} \mathrm{~cm}^{-2}$. It was observed that direct oxidation was the main removal mechanism of organic and inorganic carbon; while, the indirect oxidation in higher current density was responsible for nitrogen oxidation. Hydrocarbon in the form of colloidal particles could be removed by electro-flotation. On the other hand, electro-decomposition on the surface of cathode and precipitation by hydroxyl ions were the utmost removal pathway of metals. According to the initial experiments, operating condition was further optimized by central composite design model in different current density, treatment time, and electrolyte addition, based on the best responses on the specific energy consumption (SEC), chemical oxygen demand (COD) and total organic carbon (TOC) removal efficiency. Under optimum operating condition (current density $=23.1 \mathrm{~mA} \mathrm{~cm}^{-2}$, time $=120 \mathrm{~min}$, $\mathrm{Ti} / \mathrm{Pt}$ as a cathode and $\mathrm{Nb} / \mathrm{BDD}$ as the anode), electro-oxidation showed the following removal efficiencies: COD (84.6\%), TOC (68.2\%), oil and grease (99\%), Color $(87.9 \%)$, total alkalinity (92\%), $\mathrm{N}_{\text {tot }}(18 \%), \mathrm{NH}_{4}{ }^{+}$(31\%), Ca (66.4\%), Fe (71.1\%), Mg (41.4\%), Mn (78.1\%), $\mathrm{P}_{\text {tot }}(75 \%), \mathrm{S}$ $(67.1 \%)$, and $\mathrm{Si}(19.1 \%)$.
\end{abstract}

\title{
Keywords:
}

Oily wastewater; Electro-oxidation process; Oxidation kinetics; Optimization. 


$\begin{array}{ll}\text { Nomenclature } \\ \text { BDD } & \text { Boron-doped diamond } \\ \text { BOD } & \text { Biochemical Oxygen Demand } \\ \text { CCD } & \text { Central Composite Design } \\ \text { CD } & \text { Current Density } \\ \text { COD } & \text { Chemical Oxygen Demand } \\ \text { Ilim } & \text { Diffusion Current Limit } \\ \text { EC } & \text { Electrical Conductivity } \\ \text { FD } & \text { Factorial Design } \\ \eta & \text { Instant Current Efficiency } \\ \text { OWW } & \text { Oily Wastewater } \\ \text { SEC } & \text { Specific Energy Consumption } \\ \text { TA } & \text { Total Alkalinity } \\ \text { TCU } & \text { True Color Unit } \\ \text { TOC } & \text { Total Organic Carbon }\end{array}$




\section{Introduction}

Produced water from the petroleum refinery, oil storage and transportation, petrochemical industry, oil-drilling mud and oily contaminated soil leachate are categorized as the oily wastewater (OWW) (Yu et al. 2017). These wastewaters mostly contains high concentration of hydrocarbons, phenols, sulfides, heavy metals and ammonia $\left(\mathrm{NH}_{3}\right)$ with very high toxicity (Skban Ibrahim et al. 2014). Although utilization of specific strains of microorganism could potentially remove prevalent hydrocarbon compounds (Tazari et al. 2017), lack of biodegradable organic carbon and phosphorous brings challenges for the biological treatment processes (Yu et al. 2017). Additionally, physical separation such as, API oil-water separator and dissolved air flotation has deficiency for proper removal of fine colloids hydrocarbon with diameter of 0.1$100 \mu \mathrm{m}$ (Al-Shamrani et al. 2002, Santos et al. 2006).

Simplicity of process, ease of operation, minimal sludge production, brief retention time and high performance in the oxidation of macro and micro-pollutants makes electro-oxidation process one of the best treatment option for treatment of non-biodegradable industrial wastewater such as, oily wastewater, landfill leachate, textile dye, pulp and paper and aquaculture saline water (Bashir et al. 2013, da Silva et al. 2013, Díaz et al. 2011, Drogui et al. 2007, Zolfaghari et al. 2016). Electro-oxidation used not only used for low quantity wastewater with high electrical conductivity (EC), but also it used asfor treatment of light wastewater with COD below $800 \mathrm{mg} \mathrm{L}^{-1}$ (da Silva et al. 2013) or as the post treatment of municipal wastewater treatment plant with low energy consumption $\left(4.3 \mathrm{kWh} \mathrm{m}^{-3}\right)$ (Cao et al. 2016). In this case, energy consumption could be cut off by the addition of salt such as $\mathrm{NaCl}$ and $\mathrm{Na}_{2} \mathrm{SO}_{4}$ (Chen 2004, Díaz et al. 2011, Panizza \&Martinez-Huitle 2013). 
Basically anode materials are made up special composites that produce hydroxyl radicals $\left(\mathrm{OH}^{\circ}\right)$ instead of oxygen (Yavuz et al. 2010). Anodic pollutants oxidation on the surface of electrode and in the interface by $\mathrm{OH}^{\circ}$ was called direct oxidation (Anglada et al. 2011, Bashir et al. 2013, Cao et al. 2016). In higher current density (CD) ions and water molecule are electrochemically react with $\mathrm{OH}^{\circ}$ or directly on the surface of anode to generate mediator radicals $\underline{\text {, such as }}$ hypochlorous acid $(\mathrm{HClO})$, peroxydisulfuric acid $\left(\mathrm{H}_{2} \mathrm{~S}_{2} \mathrm{O}_{8}\right)$, hydrogen peroxide $\left(\mathrm{H}_{2} \mathrm{O}_{2}\right)$, and ozone $\left(\mathrm{O}_{3}\right)$ that oxidized the pollutants. The only removal pathway of $\mathrm{NH}_{4}{ }^{+}$was through indirect oxidation by HClO (Díaz et al. 2011, Ighilahriz et al. 2013, Li \&Liu 2009).

Compare to the other mixed metal oxide electrodes (da Silva et al. 2013), non-active BDD electrode hasshows the highest performance on hydroxyl radical generation (Zhou et al. 2016); as it showsdue to low adsorption enthalpy of $\mathrm{OH}^{\circ}$ (Martínez-Huitle \&Brillas 2008). For example, the reaction rate of phenol and COD oxidation rate using BDD was 12 times higher than RuMMO electrode, even though the current density was four times smaller (Yavuz et al. 2010).

In this study, the oxidation mechanisms of all macro-contaminants were firstly investigated by focusing on their kinetic studies. Later on, the effect of operating conditions was investigated on the process performance. Finally, the operating condition was optimized according to the best oxidation performance and energy consumption. 


\section{Material and Methods}

\subsection{Oily wastewater}

OWW was taken from the leachate of soil remediation plant, located in $5 \mathrm{~km}$ North of Quebec City, QC, Canada. The treatment plant received soil from the nearby site, which was heavily contaminated by crude petroleum. Prior to release into the environment, the soil leachate introduced to a primary settling tank for suspended solid (SS)-removal, followed by peat filtration for the adsorption of humic substances and granular activated carbon for the removal of recalcitrant hydrocarbon. In $10^{\text {th }}$ of May 2016, 60 liters of sample was taken directly from primary settling tank, instantly keeping in cold room with temperature of $4^{\circ} \mathrm{C}$, before the experiments. According to the characteristic of OWW presented in Table 1, the current treatment facility should be modified to remove effectively residual $\mathrm{NH}_{3}$, metals and total organic carbon (TOC). Deficiency of biological treatment was inevitable, due to the low ratio of BOD/COD and lack of phosphorous. Deposition of suspended solidSS on the surface of electrodes negatively influences the oxidation by increasing the electrical resistance; yet, its concentration was insignificant after the primary settling tank.

\subsection{Experimental pilot}

The electrochemical oxidation pilot was made up two Plexiglas containers in close loop: (1) reaction tank with dimension of $(14 \times 5 \times 10 \mathrm{~cm})$, (2) and a $500 \mathrm{~mL}$ storage tank. The rectangular anode/cathode electrode made up niobium coated with $4 \mu \mathrm{m}$ of boron doped diamond (Nb/BDD) (provided by DiaChem ${ }^{\circledR}$, Germany) and titanium coated with platinum (Ti/Pt) with the thickness of $0.1 \mathrm{~cm}$, specific surface area of $130 \mathrm{~cm}^{2}$ and inter-electrode gap of $1 \mathrm{~cm}$-were used. Coating of BDD on the surface of $\mathrm{Nb}$ was performed by hot filament chemical 
vapor deposition in presence of $\mathrm{KFe}(\mathrm{CN})_{6}$ under acidic condition. Niobium was also selected as the base metal, due to its high corrosion resistance, working in high temperature and high adhesion capability (Yu et al. 2013). Furthermore, BDD coating showed Nb/BDD was selected, because of high corrosive resistance, low hydroxyl radical adsorption properties, stable chemical properties and high catalytic activity (Chen 2004, Panizza et al. 2001). Stability of BDD coating was proved in this study, as the concentration of Boron was changed insignificantly during all sets of experiment (Table 1). Likewise, Ti/Pt was selected as the cathode type, due to its resistance toward nitrate reduction into ammonia (Ding et al. 2015). The electric current was provided by a DC power supply (Sorensen DCS40-75E, Magna-Power Electronics Inc., Flemington, New Jersey, USA). In order to maximized the mass transfer rate, the recycling flow

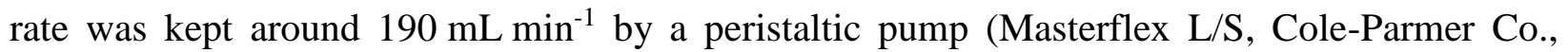
Montreal, QC, Canada) (Skban Ibrahim et al. 2014). Due to the metal electrodeposition and/or precipitation on the surface of cathode, it the electrodes submerged in the solution of $5 \%$ hydrochloric acid for 30 min after each experiment.

\subsection{Experimental design}

Kinetic studies were performed in different current density from 3.8 to $61.5 \mathrm{~mA} \mathrm{~cm}$, in order to calculate the diffusion current limit $\left(\mathrm{I}_{\mathrm{lim}}\right)$, mechanism of macro-pollutant oxidation and proper range of operating condition. Two main operating regimes control the oxidation of organic matter: (1) electronic transfer control; and (2) mass transport control (Panizza \&Martinez-Huitle 2013). In low current density, electronic transfer controlled the oxidation rate, resulted in zeroorder kinetics of COD oxidation. If COD oxidation followed first-order kinetic, oxidation was mainly controlled by mass transfer. By knowing the fact that instant current efficiency $(n)$ 
decreases below 1 for current density larger than $\mathrm{I}_{\text {lim_(equation } 1 \text { ), it gradually decreased to reach }}$ $\eta=1$. Kinetics of COD oxidation in $\mathrm{I}_{\mathrm{lim}}$ was used for experimental estimation of $\mathrm{K}_{\mathrm{m}}$, based on equation 2:

$\eta=\frac{4 F V_{R}\left(C O D_{t}-C O D_{0}\right)}{I t}$

$I_{\text {lim }}=4 F A K_{m} \operatorname{COD}(t)=4 F A K_{m} \operatorname{COD}_{0} \exp (-k t)$

Where, F stands for Faraday's constant $\left(96,487 \mathrm{C} \mathrm{mol}^{-1}\right), \mathrm{COD}_{0}$ and $\mathrm{COD}_{\mathrm{t}}$ are initial and final concentration $\left(\right.$ mol. $\left.\mathrm{L}^{-1}\right), t$ is the time of reaction, $A$ is the surface of anode $\left(\mathrm{m}^{2}\right)$, and $V_{R}$ is the volume of wastewater (L) (Boye et al. 2004).

The kinetic study was performed by measuring the residual COD, TOC, $\mathrm{N}_{\mathrm{tot}}, \mathrm{NO}_{3}{ }^{-}$and $\mathrm{NH}_{4}{ }^{+}$for each sample taken in specific period of time $(5,10,20,30,45,60,90,120 \mathrm{~min}) . \mathrm{Na}_{2} \mathrm{SO}_{4}$ with concentration of $1 \mathrm{~g} \mathrm{~L}^{-1}$ was inserted to increase the electrical conductivity from the average 2.75 to $4.89 \mathrm{~ms} \mathrm{~cm}^{-1}$. The addition of electrolyte decreased the applied electric potential, consequently decreased the energy consumption.

For understanding the statistical significance of variable parameters such as, current density $\left(\mathrm{X}_{1}\right)$, treatment time $\left(\mathrm{X}_{2}\right)$ and addition of electrolyte $\left(\mathrm{X}_{3}\right)$, factorial design $(\mathrm{FD})$ was used with specific energy consumption, COD and TOC removal efficiency as the responses. The condition of FD experiments was fixed in extreme limit with eight sets of experiments. Additional eighteen sets of experiments at the center of domain and axial assays for each categorical factor were performed for process optimization by central composite design (CCD). All the conditions and results of FD and CCD models were provided in Table 2. 
In FD, the effect of each factor and their interaction was estimated according to the following model (Equation 3):

$Y=b_{0}+b_{1} X_{1}+b_{2} X_{2}+b_{3} X_{3}+b_{12} X_{12}+b_{13} X_{13}+b_{23} X_{23}$

In which $\mathrm{Y}$ is the experimental response, $\mathrm{b}_{0}$ is the average value of response, $\mathrm{X}_{\mathrm{i}}$ is the variables, $b_{i}$ stands for effect of each factor and finally $b_{i j}$ represents interaction effect of variable $i$ and $j$ on response. Experimental coefficient (b) was measured using half difference between arithmetic averages of the responses for extreme values of variable. For the process optimization, CCD model was performed by means of 26 experiments, and-which later estimated the result by second order model(Equation 4).

$Y=b_{0}+\Sigma b_{i} X_{i}+\Sigma b_{i i} X_{i}^{2}+\Sigma b_{i j} X_{i} X_{j}+e_{i}$

In whichequation $4, b_{i}, b_{i i}$ and $b_{i j}$ are the liner, quadratic and interactive effects of specified variable and $e_{i}$ represents the residual term. Design expert software (Design Expert 7, State-Ease Inc., Minneapolis, USA) was used to calculate the coefficients of polynomial model.

The specific energy consumption ( $\mathrm{kWh} \mathrm{kg} \mathrm{COD}^{-1}$ ) was calculated according to the following equation:

$S E C=\frac{I \Delta U t}{V_{R}\left(C O D_{t}-C O D_{0}\right)}$ 
Where I stand for current intensity (A), $\Delta \mathrm{U}$ is the average cell voltage $(\mathrm{V}), \mathrm{t}$ is the treatment time (h), and COD unit is $\mathrm{g} \mathrm{L}^{-1}$ (Skban Ibrahim et al. 2014).

\subsection{Sampling and analysis}

Samples from electro-oxidation reactor were kept frozen at $-18^{\circ} \mathrm{C}$, prior to analysis. COD and color was measured by spectrophotometer (Cary 50, Varian Canada Inc., Mississauga, ON, Canada). TOC and $\mathrm{N}_{\text {tot }}$ were analyzed using a Shimadzu TOC 5000A/ TNM-L analyzer (Shimadzu Co., Laval, Qc, Canada). Lachat Instrument was used for analyzing ammonium $\left(\mathrm{NH}_{4}{ }^{+}\right)$, nitrite $\left(\mathrm{NO}_{2}^{-}\right)$, nitrate $\left(\mathrm{NO}_{3}^{-}\right)$and ortho-phosphate $\left(\mathrm{PO}_{4}{ }^{3-}\right)$ assimilated by QuikChem method 10-107-06-2-B, 10-107-4-2-A and 10-115-01-1-B, respectively. Total alkalinity (TA) was analyzed based on colorimetric titration with $0.02 \mathrm{~N}$ of sulfuric acid solution in the presence of methyl orange. Around $15 \mathrm{~mL}$ of each sample was digested by $3 \mathrm{~mL}$ of hydrogen peroxide in the presence of $2 \mathrm{~mL}$ of nitric acid before inserting into the ICP/MS for the metal analysis. The procedure of extraction and analysis of metal are fully describe in previous studies_(Zolfaghari et al. 2016). 


\section{Results and Discussion}

\subsection{Estimation of limiting current density}

While working under galvanostatic conditions, it can be possible to identify two different operating regimes; i) electronic transfer control and ii) mass transport control. $\mathrm{I}_{\text {lim }}$ is the current intensity for which the rate of pollutant removal is maximal (Equation 2). When the electrolysis is under current control $\left(\mathrm{I}<\mathrm{I}_{\text {lim }}\right)$, the instantaneous current efficiency is equal to $100 \%$ and $\underline{\mathrm{COD}}$ removal rate of COD removal-is constant. However, when the electrolysis is under mass transport control ( $\left.\mathrm{I}>\mathrm{I}_{\text {lim }}\right)$, the applied current density exceed the limiting-current density- and secondary reactions (such as oxygen evolution) takes place, resulting in a decrease of the instantaneous current efficiency $(\eta)$. Energy consumption is the most decisive factor in the selection of advanced oxidation processes. Increasing the efficiency of the process is the main objective that measured by gradual increase of current density. Experimental calculation of $\mathrm{I}_{\mathrm{lim}}$ and $\mathrm{K}_{\mathrm{m}}$ requires calculation of $\eta$ in different range of current density. According to the results presented in Figure 1, the limited current density occurred at $6.2 \mathrm{~mA} \mathrm{~cm}^{-2}$, as the $\eta$ was becoming so close to $100 \%$. By considering the homogenous first-order kinetic constant rate in $\mathrm{I}_{\text {lim }}$ (Equation 2), the calculated value of $\mathrm{K}_{\mathrm{m}}$ was around $14.7 \mu \mathrm{m} \mathrm{s}^{-1}$ which that was close to the value of 10 (Körbahti \&Artut 2010), 17.5 (Anglada et al. 2011) and $30 \mu \mathrm{m} \mathrm{s}^{-1}$ (Panizza \&Martinez-Huitle 2013) reported in literature. It is worth mentioning that in current intensity below $\mathrm{I}_{\text {lim }}$ no side reaction was happening, resulting in insignificant ammonia oxidation. Therefore, $\mathrm{I}_{\text {lim }}$ was considered as the minimum range for current intensity. 


\subsection{Organic and inorganic carbon removal}

Mechanisms of electro-oxidation of each macro-pollutant could be interpreted by its kinetic model. For $\mathrm{I}_{\text {app }}<\mathrm{I}_{\text {lim }}$, operating regime was under current intensity control in which the rate of pollutant oxidation was constant (Díaz et al. 2011). In the case of our experiment, oxidation rate was always controlled by mass transfer. According to the results (showed in supplement: Table 1-S), oxidation of carbon macro-pollutants include COD, TOC, color, and TA perfectly described by the pseudo first order kinetics with $\mathrm{R}^{2}$ of $90 \%$ for all current density (Anglada et al. 2011, Bashir et al. 2013, Urtiaga et al. 2009). As illustrated in Figure 2.a, by increasing CD from 7.7 to $38.5 \mathrm{~mA} \mathrm{~cm}{ }^{-2}$, oxidation half-life decreased rapidly, followed by gradual increase till $61.5 \mathrm{~mA} \mathrm{~cm}$. This trend was also detected in previous studies for the treatment of refinery wastewater (Ighilahriz et al. 2013, Skban Ibrahim et al. 2014). As it shown in Figure 3, oxidation occurs in three different sections: (1) direct electric oxidation on the surface of anode (Espinoza et al. 2016), (2) $\mathrm{OH}^{\circ}$ oxidation in the interface with formation potential of $2.8 \mathrm{~V}$ (3) bulk or indirect oxidation by mediators, such as $\mathrm{HClO}$ with $\mathrm{E}^{\circ}=1.48 \mathrm{~V}$ and $\mathrm{H}_{2} \mathrm{~S}_{2} \mathrm{O}_{8}$ with $\mathrm{E}^{\circ}=2.10 \mathrm{~V}$ (Espinoza et al. 2016, Panizza et al. 2001). Increase current density more than its critical value, caused side reaction of $\mathrm{O}_{2}$ and $\mathrm{Cl}_{2}$ production instead of hydroxyls radical on the surface of anode (Santos et al. 2006). Although it decreased dramatically the $\eta$ yet, additional indirect oxidation increased the constant rate of carbon oxidation. The half-life oxidation of COD, for example was between 30 to $100 \mathrm{~min}$ for the current density of 38.5 and $7.7 \mathrm{~mA} \mathrm{~cm}{ }^{-2}$, respectively. As shown in Figure 3, oxidation of water molecule on the surface of BDD resulted in simultaneous production $\mathrm{OH}^{\circ}$, and $\mathrm{H}^{+}$. Alkalinity includes $\mathrm{CO}_{3}{ }^{2-}$ and $\mathrm{HCO}_{3}{ }^{-}$was acted as the buffer and neutralized the excess protons; therefore, for the first hour of the reaction $\mathrm{pH}$ remained unchanged (the result is presented in Figure 1-S). Furthermore, reaction of alkalinity 
with $\mathrm{OH}^{\circ}, \mathrm{O}_{3}$, and $\mathrm{H}_{2} \mathrm{O}_{2}$ at the beginning of operation led to the production of $\mathrm{OH}^{-}$, which even raised pH in the first thirty minutes of the experiment (Ighilahriz et al. 2013, Zhou et al. 2016). Previous studies showed that oxidation rate constant was enhanced in higher $\mathrm{pH}$, since it induced generation of more $\mathrm{OH}^{\circ}$ from mediator in the bulk (Alizadeh Kordkandi \&Mohaghegh Motlagh 2017). Both reactions resulted in rapid oxidation rate with half-life of 25-64 min for the current density of 38.5 and $7.7 \mathrm{~mA} \mathrm{~cm}{ }^{-2}$, respectively. TOC, on the other hand, had the lowest kinetic constant (between 0.14 to $0.89 \mathrm{~h}^{-1}$ ), as the total mineralization of organic carbon to $\mathrm{CO}_{2}$ was required. Finally, electro-floatation led to have complete removal hydrophobic oil and grease $(\mathrm{O} \& \mathrm{G})$ in very short time. Oxygen as a side reaction in anode, and hydrogen in cathode, produced fine bubbles range from 15 to $60 \mu \mathrm{m}$ in the anode and $8-15 \mu \mathrm{m}$ in the cathode that attached to the pollutants, floated them on the surface (Drogui et al. 2007, Santos et al. 2006). It worth mentioning that rate of electro-flotation rapidly increased in higher current density; yet it had insignificant effect on TOC and COD kinetic rate in our case due to small share of O\&G from total organic carbon (11\%) (Santos et al. 2006). Complete removal of total petroleum hydrocarbon in just 24 min was also reported in previous studies by $\mathrm{CD}$ of $30 \mathrm{~mA} \mathrm{~cm}{ }^{-2}$ (Rocha et al. 2012, Skban Ibrahim et al. 2014).

\subsection{Nitrogen removal}

In electro-oxidation process, ammonia is only removed by reaction with $\mathrm{HClO}$ or $\mathrm{ClO}^{-}$to produce chloramines (Figure 3). As you can see in Table 1, decrease in concentration of chlorine by $90 \%$ was result of its reaction with ammonia. As the concentration of $\mathrm{HClO}$ should be considered in ammonia oxidation, $\mathrm{N}_{\text {tot }}$ and $\mathrm{NH}_{4}{ }^{+}$oxidation were fitted with second-order reaction with $\mathrm{R}^{2}$ of $95 \%$ for the current density higher than $7.7 \mathrm{~mA} \mathrm{~cm}^{-2}$; yet, production of $\mathrm{NO}_{3}^{-}$from oxidation of $\mathrm{NH}_{4}{ }^{+}$, followed zero order kinetic. As the reaction on the surface of electrode 
followed the zero-order kinetics (Figure 2.b), it could be deduced that production of nitrate mainly happened by the oxidation of ammonia on the surface of electrode. On the other hand, indirect oxidation by $\mathrm{HClO}$ in the bulk frequently targeted $\mathrm{NH}_{4}{ }^{+}$oxidation into nitrogen gases ( $\mathrm{N}_{2}$ ) (Cao et al. 2016, Ighilahriz et al. 2013, Li \&Liu 2009). Therefore, $\mathrm{N}_{\text {tot }}$ and $\mathrm{NH}_{4}{ }^{+}$was followed the second-order reaction (Díaz et al. 2011). If the operating condition was not in favor indirect oxidation (in acidic $\mathrm{pH}$, low current density and $\mathrm{Cl}^{-}$concentration), linear profile of nitrogen oxidation (zero order kinetic) was detected (Díaz et al. 2011).

Half-life of carbon pollutant oxidation was at least ten times faster than nitrogen pollutants halflife (3 to $24 \mathrm{~h}$ ) in different current densities. Low oxidation rates of $\mathrm{NH}_{4}{ }^{+}$and $\mathrm{N}_{\text {tot }}$ were also reported in previous studies (Urtiaga et al. 2009).

\subsection{Metal removal}

Unlike-nitrogen, inorganic and organic nitrogen and carbon, metals should be reduced on the cathode by electro-deposition. Metal precipitation by hydroxide ions $\left(\mathrm{OH}^{-}\right)$was the second pathway of metal removal, especially in higher current density. According to Figure 3, Mg and $\mathrm{Ca}$ were precipitated in the presence of $\mathrm{OH}^{-}$produced by bicarbonate oxidation. Therefore, removal efficiency more than 50\% was expected for both $\mathrm{Mg}$ and $\mathrm{Ca}$. In lower current density, initial sulfur concentration rarely changed; yet in current density higher than $23.1 \mathrm{~mA} \mathrm{~cm}{ }^{-2}$, sulfate ions was transformed to $\mathrm{H}_{2} \mathrm{~S}_{2} \mathrm{O}_{8}$ by reaction with $\mathrm{OH}^{\circ}$, dramatically reduced average $\mathrm{S}$ concentration from 372 to $121 \mathrm{mg} \mathrm{L}^{-1}$ (Table 1). It is possible that metal cations formed a solid complex with $\mathrm{S}_{2} \mathrm{O}_{8}{ }^{2-}$ ions (Dvorak et al. 1992). For the metal with no interaction with anions, electro-deposition was the basic removal pathway. As respect of their positive charge, they readily adsorbed on the surface of cathode and reduced to free metal. According to Figure 4, 
except $\mathrm{Na}, \mathrm{K}, \mathrm{B}$ and $\mathrm{Si}$, removal efficiencies of metal were larger than $50 \%$ using different current intensities. In comparison with $\mathrm{Fe}, \mathrm{Mg}, \mathrm{Mn}$ and $\mathrm{Ca}$, no removal of highly reactive metal such as B, Na and K was reported in literatures (da Silva et al. 2013, Rocha et al. 2012).

Silicon was mostly found in colloids and suspended solid, due to leaching of silica from the soil. Although, organic matter aggregates were easily broken, decreasing the turbidity (Table 1) (Santos et al. 2006), inorganic particles was basically inactive toward reduction; so, removal efficiency of silicon was very low and fluctuated between 19 to $26 \%$ in different operating condition (Figure 4). As the concentration of metal, alkalinity, and sulfate was decreased, electrical conductivity was gradually decreased throughout the experiment (the result is presented in Figure 2-S).

\subsection{Process Optimization}

Type of electrodes, current density, electrolyte addition, recycling flow rate and $\mathrm{pH}$ are among the most important factors on the energy consumption and performance of electro-oxidation. To have the highest performance, type of electrode and circulation flow rate was fixed. Moreover, fixing $\mathrm{pH}$ was not recommended, due to its operational obstacle. Therefore, current density, treatment time and electrolyte addition wasere the only variables for the optimization.

In order to having COD below discharge regulation $\left(160 \mathrm{mg} \mathrm{L}^{-1}\right)$, the range of $23-38.5 \mathrm{~mA} \mathrm{~cm}^{-2}$ of current density, 1-2 hours of treatment time was selected. FD model was run for eight sets of experiments to figure out the following models for SEC, COD and TOC removal (Equation 6-8):

$\operatorname{COD} R E(\%)=70.21+9.14 \mathrm{X}_{1}+9.92 \mathrm{X}_{2}-5.65 \mathrm{X}_{3}-1.58 \mathrm{X}_{12}+5.38 \mathrm{X}_{13}$ 
$\mathrm{R}^{2}=0.996$

TOC RE $(\%)=53.70+9.33 \mathrm{X}_{1}+15.34 \mathrm{X}_{2}-8.27 \mathrm{X}_{3}+3.17 \mathrm{X}_{13}+2.45 \mathrm{X}_{23}$

$\mathrm{R}^{2}=0.990$

$\operatorname{SEC}(\mathrm{kWh} / \mathrm{kgCOD})=100.37+20.86 \mathrm{X}_{1}+19.82 \mathrm{X}_{2}-19.22 \mathrm{X}_{3}+7.33 \mathrm{X}_{12}-11.19 \mathrm{X}_{13}$

$\mathrm{R}^{2}=0.993$

The predicted correlation coefficients were $0.94,0.84,0.89$, respectively, which exceeded 0.8 , showed high predictability of models. Based on Pareto chart (Figure 2-S), influence of each factors and their interaction on the responses were fully described. As shown in Figure 5, and Table 2 treatment time had the largest effect on COD removal efficiency. Effect of this factor on TOC removal efficiency was more pronounced. As it expected, electrolyte addition had significant effect on the energy consumption. Strangely, this factor negatively affected COD and TOC removal efficiency (Equations 6 and 7), even though it claimed that addition of electrolyte was conductive for oxidation rate (Skban Ibrahim et al. 2014). As indirect oxidation rate decreased in acidic solution, decreasing $\mathrm{pH}$ during the electro-oxidation process negatively affect the reaction capacity of mediator, decreasing COD and TOC removal efficiencies. It seems that electrolyte addition was also negatively affected the indirect oxidation of ammonia, as it decreased $\mathrm{NH}_{4}{ }^{+}$and $\mathrm{N}_{\text {tot }}$ removal efficiencies from the range of $29-39 \%$ and $12-23 \%$ to $14-29 \%$ and 9-21\%, respectively. As shown in Figure 3, indirect oxidation by $\mathrm{HClO}$ was the main removal pathway of ammonia. This reaction was mostly determined by the concentration of 
chloride and $\mathrm{pH}$ ( $\mathrm{Li} \& \mathrm{Liu} 2009$ ). By increasing the concentration of $\mathrm{SO}_{4}{ }^{2-}$, the rate of $\mathrm{HClO}$ production was decreased, leading in lower ammonia oxidation. Furthermore, $\mathrm{pH}$ of the effluent was decreased more rapidly in presence of salt. Therefore, ammonia oxidation was inhibited ( $\mathrm{Li}$ \&Liu 2009).

For the process optimization, CCD model was used to model the responses according to the following equation (Equation 9 and 11).

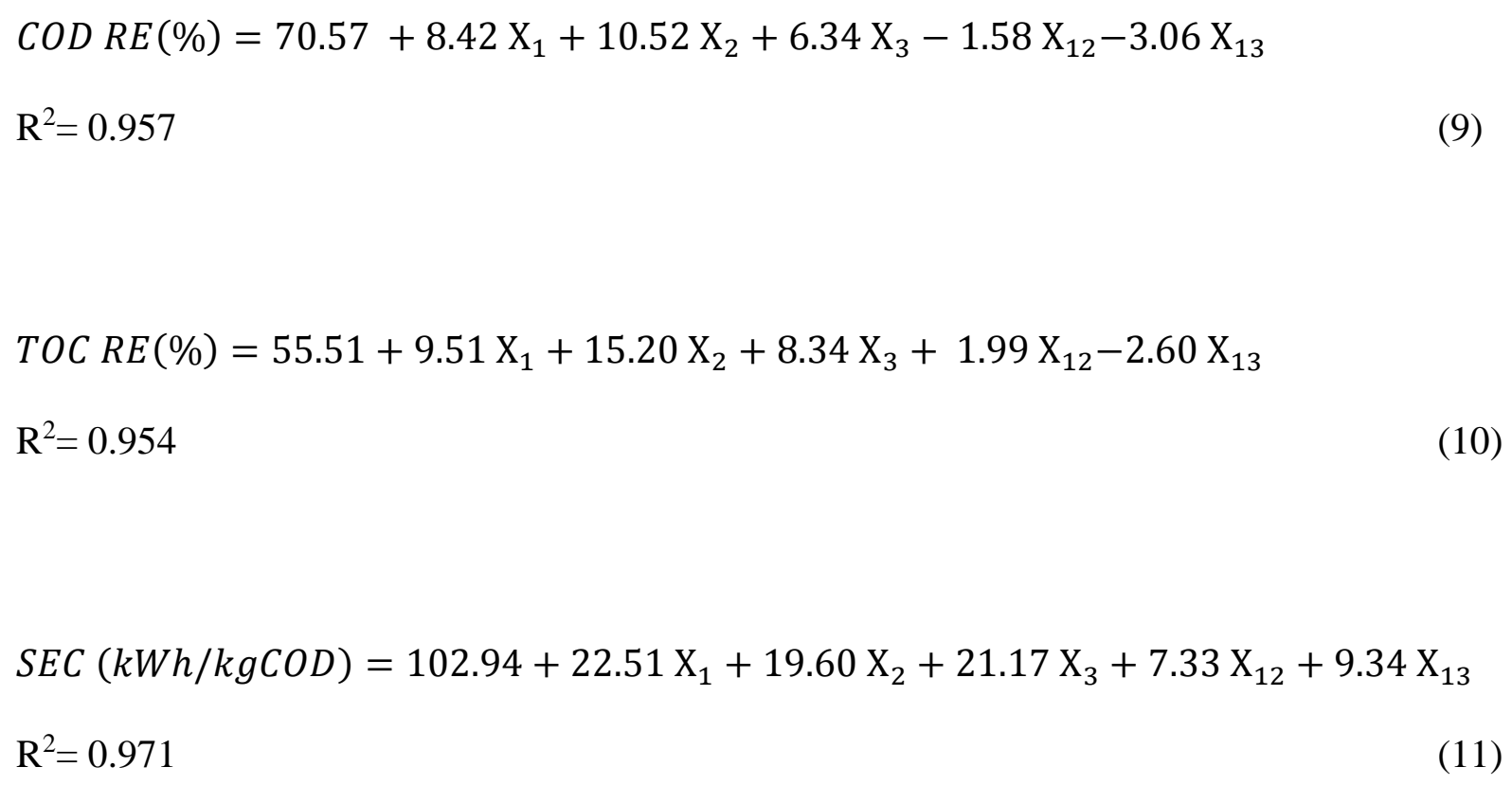

Significance of the following models was assessed by the ANOVA test, based on $95 \%$ of the confidential level. Calculated $\mathrm{F}$ values for equation 9 to 11 were 88,82 , and 132 , respectively that were superior to Fc value (predictably of model are shown in supplement: Figure 3-S). For the optimization of operating condition, maximizing TOC and COD removal efficiencies, and minimizing energy consumption was considered. Based on the models (result presented in 
Figure 4-S) the following operating condition was required: Anode type: Nb/BDD, Cathode type: Ti/Pt, current density of $23.1 \mathrm{~mA} \mathrm{~cm}^{-2}$, treatment time: $120 \mathrm{~min}$ without addition of electrolyte. For the final validation of models, three experiments run in this condition with the results presented in Table 1. Even though COD and TOC showed high removal rate, BOD was rarely decreased, as the organic carbon in the effluent had very low molecular weight with high bioavailability. Low production of $\mathrm{NO}_{3}=$ by anodic oxidation of $\mathrm{NH}_{3}$ was also detected, as the most ammonia in the form of $\mathrm{NH}_{4}{ }^{+}$had lower affinity toward anode. $\eta$ and current efficiency were measured around 47.4 and $48.7 \%$. The energy consumption required for the oxidation of oily wastewater was estimated around $102 \mathrm{kWh} \mathrm{kg} \mathrm{COD}^{-1}$ or $86.4 \mathrm{kWh} \mathrm{m}^{-3}$ that was comparable with the results in the literature. 


\section{Conclusion}

Proper treatment of pollutants from oily wastewater was reached by utilization of electrochemical oxidation process; while, physical and biological processes faced serious treatment challenges. In the anode surface, organic nitrogen and carbon could oxidized and produced $\mathrm{CO}_{2}$ and $\mathrm{NO}_{3}{ }^{-}$with zero order kinetic rate. The remaining organic and inorganic carbon was mostly targeted by hydroxyl radical with first-order kinetic rate. Indirect oxidation in bulk, especially with $\mathrm{HClO}$, was responsible for $\mathrm{N}_{\text {tot }}$ removal with second-order reaction. Electro-floatation and electro-deposition were simultaneously occurred. Rapid removal of oil and grease was resulted from flotation by the fine hydrogen and oxygen bubbles produced in the cathode and anode, respectively. Reduction on the cathode and precipitation by sulfur and $\mathrm{OH}^{-}$were the main removal pathways of metals.

Testing different current density, treatment time and electrolyte addition showed that the effect of the first factor was equal on COD removal efficiency and energy consumption (34.4 and $31.6 \%$, respectively); while, the effect of last was more pronounced in energy consumption than removal efficiencies $(26.8,16.8,13.2 \%$, respectively). Treatment time was the most important factor on the performance of the process.

By optimizing the process, the following result was observed for current density of $23.1 \mathrm{~mA} \mathrm{~cm}^{-2}$ during 120 min: Removal efficiencies higher than $75 \%$ were measured for oil and grease, color, total alkalinity, $\mathrm{COD}, \mathrm{S}, \mathrm{PO}_{4}{ }^{3-}, \mathrm{Al}, \mathrm{Fe}, \mathrm{Mn}$ and $\mathrm{Ca}$. TOC, BOD, $\mathrm{P}_{\text {tot }}, \mathrm{Mg}, \mathrm{S}$ had medium removal rates. Finally, removal efficiencies lower than $25 \%$ were detected for $\mathrm{N}_{\mathrm{tot}}, \mathrm{NH}_{4}^{+}, \mathrm{K}$, and Na. 


\section{References}

Al-Shamrani AA, James A, Xiao H (2002): Destabilisation of oil-water emulsions and separation by dissolved air flotation. Water Research 36, 1503-1512

Alizadeh Kordkandi S, Mohaghegh Motlagh A (2017): Optimization of peroxone reaction rate using metaheuristic approach in the dearomatization and discoloration process. Environmental Progress \& Sustainable Energy, 1-8

Anglada A, Urtiaga A, Ortiz I, Mantzavinos D, Diamadopoulos E (2011): Boron-doped diamond anodic treatment of landfill leachate: evaluation of operating variables and formation of oxidation byproducts. Water Res 45, 828-38

Bashir MJK, Aziz HA, Aziz SQ, Abu Amr SS (2013): An overview of electro-oxidation processes performance in stabilized landfill leachate treatment. Desalination and Water Treatment 51, 21702184

Boye B, Brillas E, Marselli B, Michaud P-A, Comninellis C, Dieng MM (2004): Electrochemical decontamination of waters by advanced oxidation processes (AOPS): Case of the mineralization of 2, 4, 5-T on BDD electrode. Bulletin of the Chemical Society of Ethiopia 18

Cao Z, Wen D, Chen H, Wang J (2016): Simultaneous Removal of COD and Ammonia Nitrogen Using a Novel Electro-Oxidation Reactor: A Technical and Economic Feasibility Study. International Journal of Electrochemical Science, 4018-4026

Chen G (2004): Electrochemical technologies in wastewater treatment. Separation and Purification Technology 38, 11-41

da Silva AJC, dos Santos EV, de Oliveira Morais CC, Martínez-Huitle CA, Castro SSL (2013): Electrochemical treatment of fresh, brine and saline produced water generated by petrochemical industry using Ti/IrO2-Ta2O5 and BDD in flow reactor. Chemical Engineering Journal 233, 4755

Díaz V, Ibáñez R, Gómez P, Urtiaga AM, Ortiz I (2011): Kinetics of electro-oxidation of ammonia-N, nitrites and COD from a recirculating aquaculture saline water system using BDD anodes. Water Research 45, 125-134

Ding J, Li W, Zhao Q-L, Wang K, Zheng Z, Gao Y-Z (2015): Electroreduction of nitrate in water: Role of cathode and cell configuration. Chemical Engineering Journal 271, 252-259

Drogui P, Blais J-F, Mercier G (2007): Review of electrochemical technologies for environmental applications. Recent patents on engineering 1, 257-272

Dvorak DH, Hedin RS, Edenborn HM, McIntire PE (1992): Treatment of metal-contaminated water using bacterial sulfate reduction: Results from pilot-scale reactors. Biotechnology and bioengineering 40, 609-616

Espinoza JDG, Drogui P, Zolfaghari M, Dirany A, Ledesma MTO, Gortáres-Moroyoqui P, Buelna G (2016): Performance of electrochemical oxidation process for removal of di (2-ethylhexyl) phthalate. Environmental Science and Pollution Research 23, 12164-12173

Ighilahriz K, Ahmed MT, Djelal H, Maachi R (2013): Electrocoagulation and electro-oxidation treatment for the leachate of oil-drilling mud. Desalination and Water Treatment 52, 5833-5839

Körbahti BK, Artut K (2010): Electrochemical oil/water demulsification and purification of bilge water using Pt/Ir electrodes. Desalination 258, 219-228 
Li L, Liu Y (2009): Ammonia removal in electrochemical oxidation: Mechanism and pseudo-kinetics. Journal of hazardous materials 161, 1010-1016

Martínez-Huitle CA, Brillas E (2008): Electrochemical alternatives for drinking water disinfection. Angewandte Chemie International Edition 47, 1998-2005

Panizza M, Michaud P, Cerisola G, Comninellis C (2001): Anodic oxidation of 2-naphthol at borondoped diamond electrodes. Journal of Electroanalytical Chemistry 507, 206-214

Panizza M, Martinez-Huitle CA (2013): Role of electrode materials for the anodic oxidation of a real landfill leachate--comparison between Ti-Ru-Sn ternary oxide, $\mathrm{PbO}(2)$ and boron-doped diamond anode. Chemosphere 90, 1455-60

Rocha JHB, Gomes MMS, Fernandes NS, da Silva DR, Martínez-Huitle CA (2012): Application of electrochemical oxidation as alternative treatment of produced water generated by Brazilian petrochemical industry. Fuel processing technology 96, 80-87

Santos MR, Goulart MO, Tonholo J, Zanta CL (2006): The application of electrochemical technology to the remediation of oily wastewater. Chemosphere 64, 393-399

Skban Ibrahim D, Seethala Devi P, Veerababhu C, Balasubramanian N (2014): Treatment of Petroleum Effluent Using a Tubular Electrochemical Reactor. Petroleum Science and Technology 32, 19321939

Tazari F, Rahaie M, Zarmi AH, Jalili H, Yazdian F, Kordkandi SA (2017): A Systematic Comparison of Biosurfactant Effects on Physicochemical Properties and Growth Rates of P. aeruginosa MM1011 and TMU56: A Bioremediation Perspective. Bioprocess Engineering 1, 14-20

Urtiaga A, Rueda A, Anglada A, Ortiz I (2009): Integrated treatment of landfill leachates including electrooxidation at pilot plant scale. Journal of hazardous materials 166, 1530-4

Yavuz Y, Koparal AS, Öğ̈̈tveren ÜB (2010): Treatment of petroleum refinery wastewater by electrochemical methods. Desalination 258, 201-205

Yu L, Han M, He F (2017): A review of treating oily wastewater. Arabian Journal of Chemistry 10, 19131922

Yu Z-m, Jian W, WEI Q-p, Meng L-c, Hao S-m, Fen L (2013): Preparation, characterization and electrochemical properties of boron-doped diamond films on $\mathrm{Nb}$ substrates. Transactions of Nonferrous Metals Society of China 23, 1334-1341

Zhou B, Yu Z, Wei Q, Long H, Xie Y, Wang Y (2016): Electrochemical oxidation of biological pretreated and membrane separated landfill leachate concentrates on boron doped diamond anode. Applied Surface Science 377, 406-415

Zolfaghari M, Jardak K, Drogui P, Brar SK, Buelna G, Dubé R (2016): Landfill leachate treatment by sequential membrane bioreactor and electro-oxidation processes. Journal of environmental management 184, 318-326 


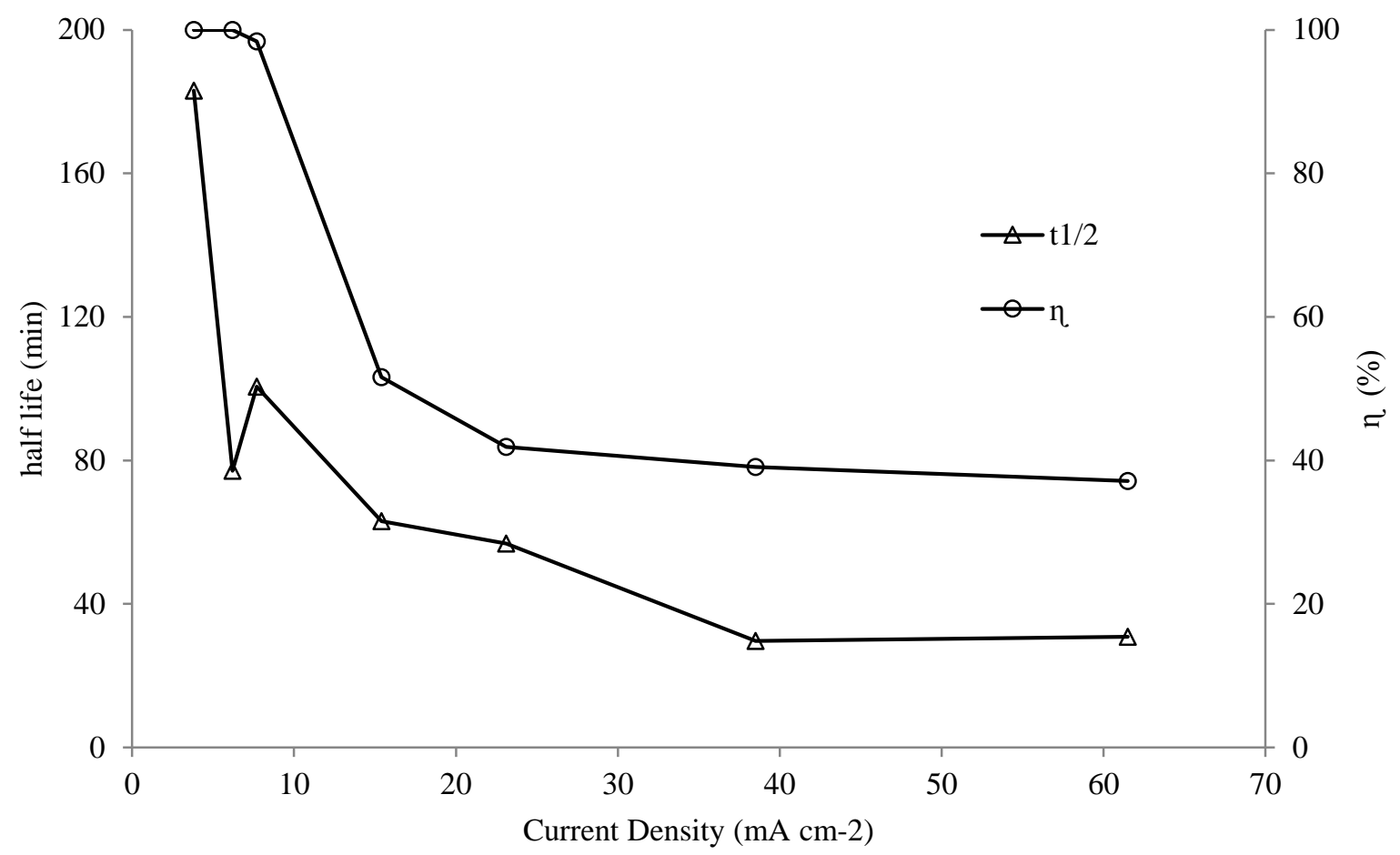

Figure 1. The apparent COD oxidation half-life and instantons current efficiency in different current densities. 


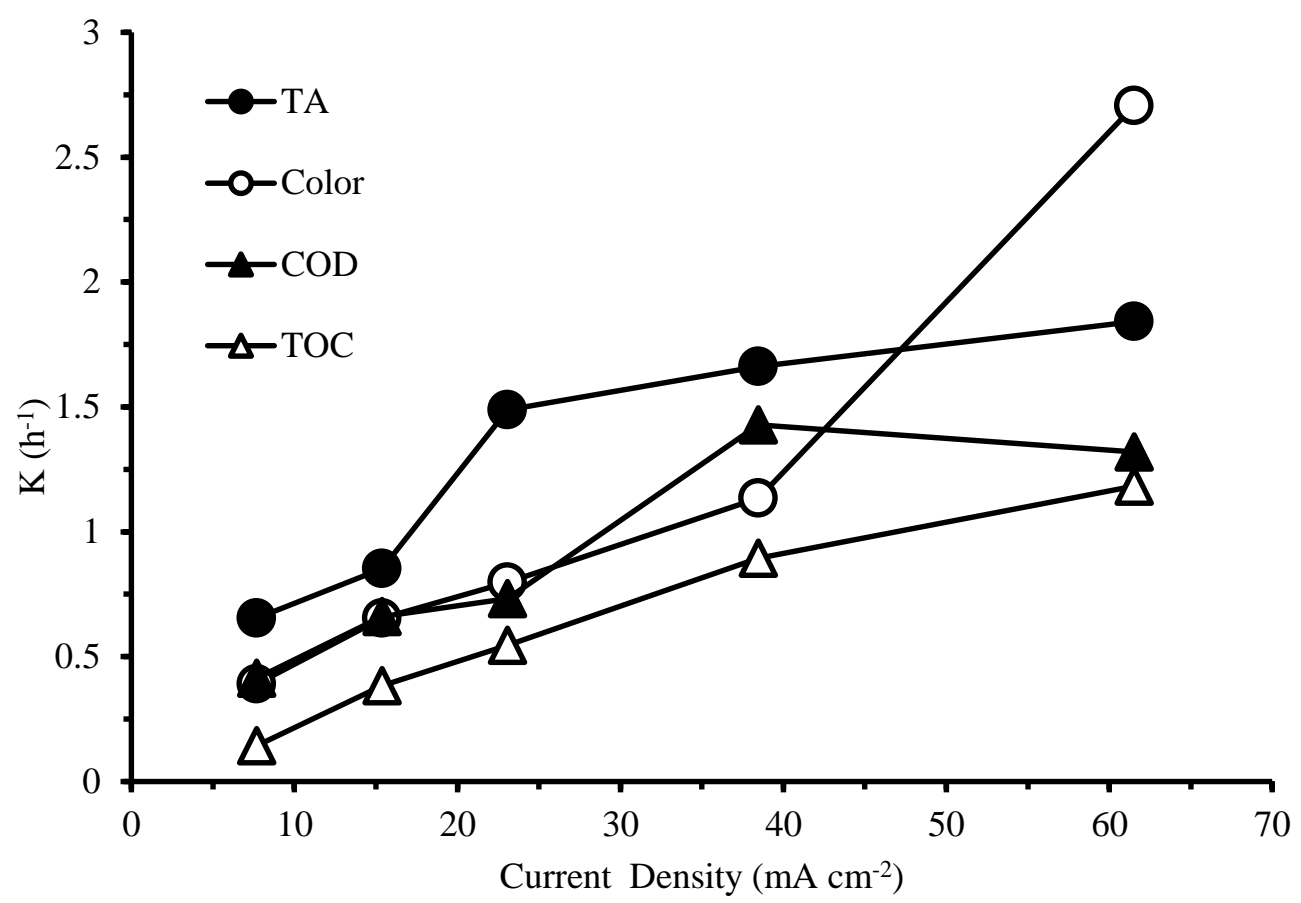

(a)

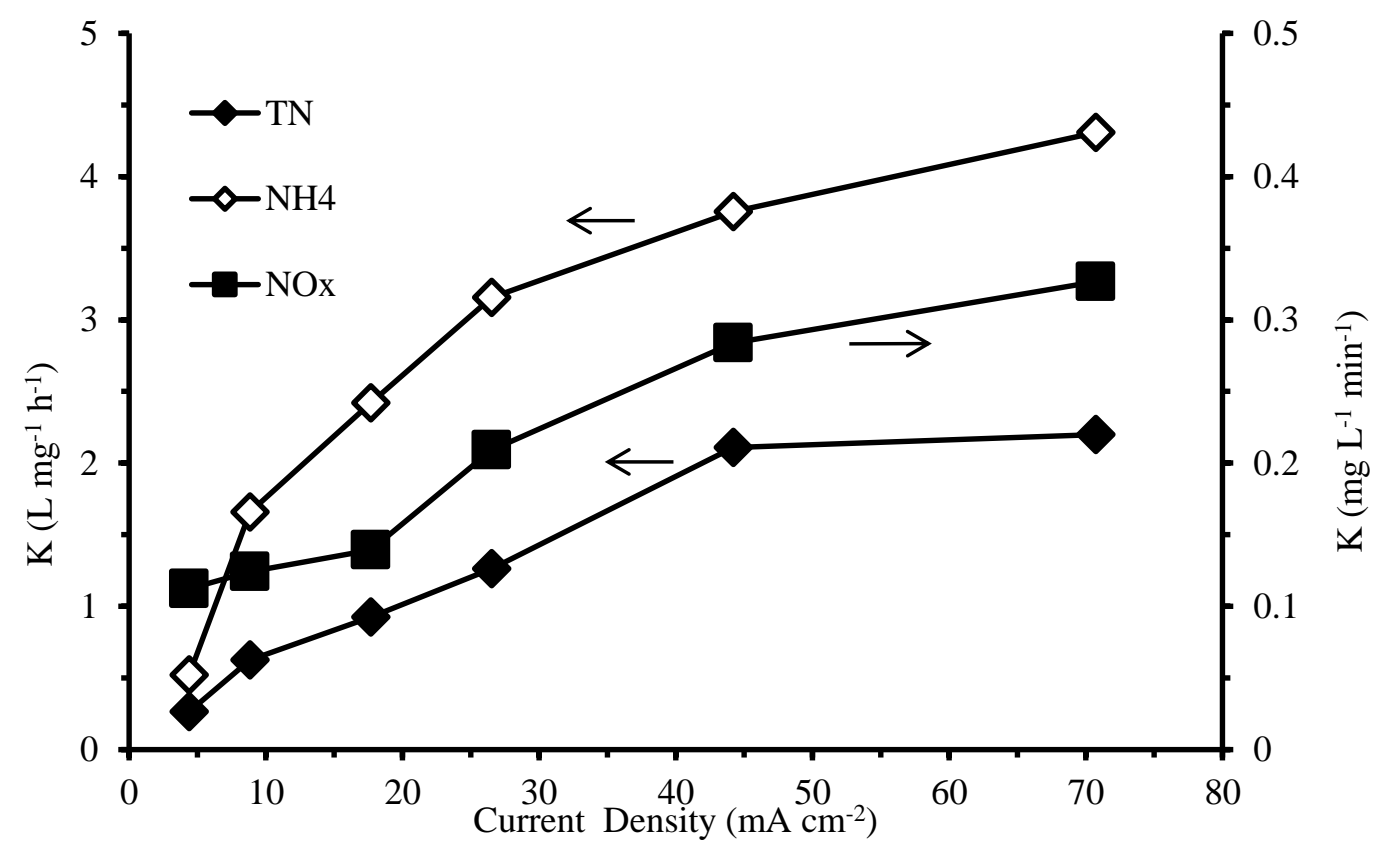

(b)

Figure 2. The apparent reaction rate constant of (a) pseudo-first order kinetic for COD, TOC, TA, and color (b) pseudo-second and zero order kinetic for $\mathrm{N}_{\text {tot }}, \mathrm{NH}_{4}{ }^{+}, \mathrm{NO}_{3}{ }^{-}$in different current densities. 
Cathode

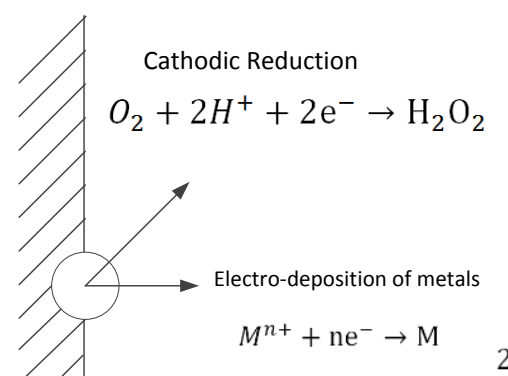

$M^{n+}+\mathrm{ne}^{-} \rightarrow \mathrm{M}$

Precipitation of Metals

$M^{n+}+\mathrm{nOH}^{-} \rightarrow \mathrm{M}(\mathrm{OH})_{\mathrm{n}}$

Precipitation of $\mathrm{Mg}$ and $\mathrm{Ca}$

$\mathrm{Ca}\left(\mathrm{HCO}_{3}\right)_{2}+\mathrm{Ca}(\mathrm{OH})_{2} \rightarrow \mathrm{CaCO}_{3}+2 \mathrm{H}_{2} \mathrm{O}$

$\mathrm{Mg}\left(\mathrm{HCO}_{3}\right)_{2}+2 \mathrm{Ca}(\mathrm{OH})_{2} \rightarrow 2 \mathrm{CaCO}_{3}+\mathrm{Mg}(\mathrm{OH})_{2}+2 \mathrm{H}_{2} \mathrm{O}$

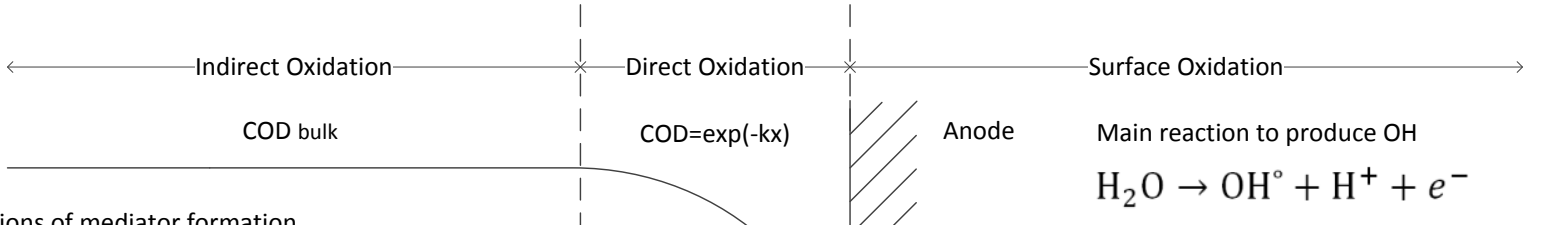

Main reaction to remove color $\mathrm{BDD}+\mathrm{H}_{2} \mathrm{O} \rightarrow \mathrm{BDD}\left(\mathrm{OH}^{\circ}\right)+\mathrm{H}^{+}+e^{-}$

$\mathrm{COD}=0$ Ammonia Oxidation, total nitrogen removal $2 \mathrm{NH}_{4}^{+}+3 \mathrm{HOCl} \rightarrow 3 \mathrm{~N}_{2}+3 \mathrm{H}_{2} \mathrm{O}+5 \mathrm{H}^{+}+3 \mathrm{Cl}^{-}$ $\mathrm{NH}_{4}^{+}+4 \mathrm{HOCl} \rightarrow \mathrm{NO}_{3}^{-}+\mathrm{H}_{2} \mathrm{O}+6 \mathrm{H}^{+}+4 \mathrm{Cl}^{-}$

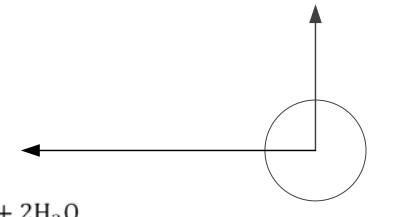

coD Oxidation $2 \mathrm{OH}^{\circ}+\mathrm{R} \rightarrow \mathrm{H}_{2}+\mathrm{RO}_{2}$

TOC removal

$\mathrm{xOH}^{\circ}+\mathrm{R} \rightarrow \mathrm{yCO}_{2}+\mathrm{zH}_{2} \mathrm{O}$
TA Oxidation

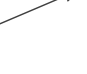

$\mathrm{BDD}\left(\mathrm{OH}^{\circ}\right)_{3}+\mathrm{NH}_{4}^{+} \rightarrow \mathrm{BDD}+\mathrm{NO}_{3}^{-}+3 \mathrm{H}^{+}+e^{-}$

Side reaction in high current intensity $\mathrm{BDD}\left(\mathrm{OH}^{\circ}\right) \rightarrow \mathrm{BDD}+1 / 2 \mathrm{O}_{2}+\mathrm{H}^{+}+e^{-}$

$$
2 \mathrm{Cl}^{-} \rightarrow \mathrm{Cl}_{2}+2 e^{-}
$$

$\mathrm{HCO}_{3}^{-}+\mathrm{OH}^{\circ} \rightarrow \mathrm{OH}^{-}+\mathrm{CO}_{2}$

$\mathrm{HCO}_{3}^{-}+H^{+} \rightarrow \mathrm{H}_{2} \mathrm{O}+\mathrm{CO}_{2}$
Ammonia surface oxidation

Figure 3. Removal mechanism of all macro-pollutants by electro-oxidation process. 


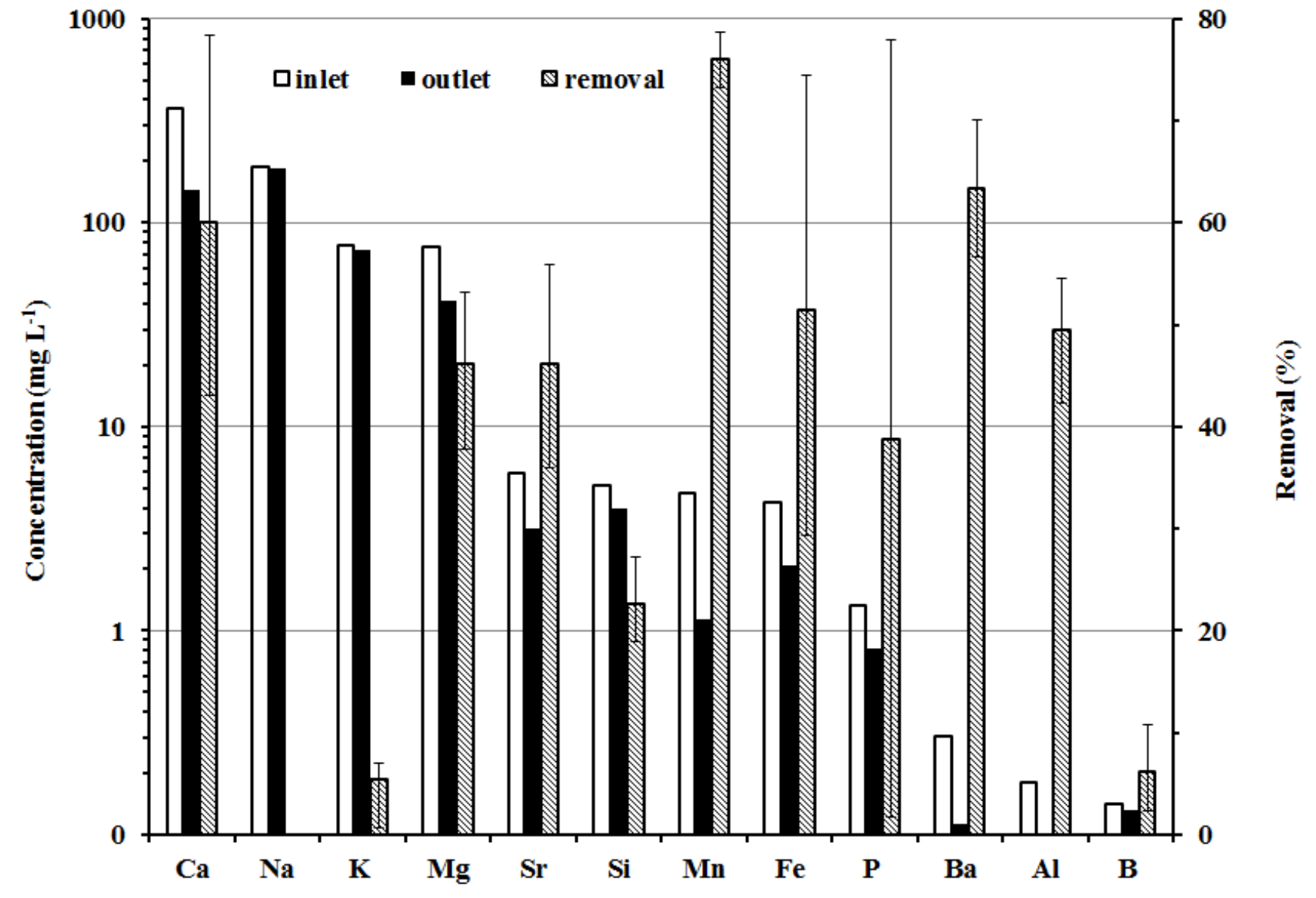

Figure 4. Average removal efficiency, influent and effluent concentration of metal cations in different treatment time (1-3 h) and current density (3.8-61.5 $\mathrm{mA} \mathrm{cm}^{-2}$ ). 


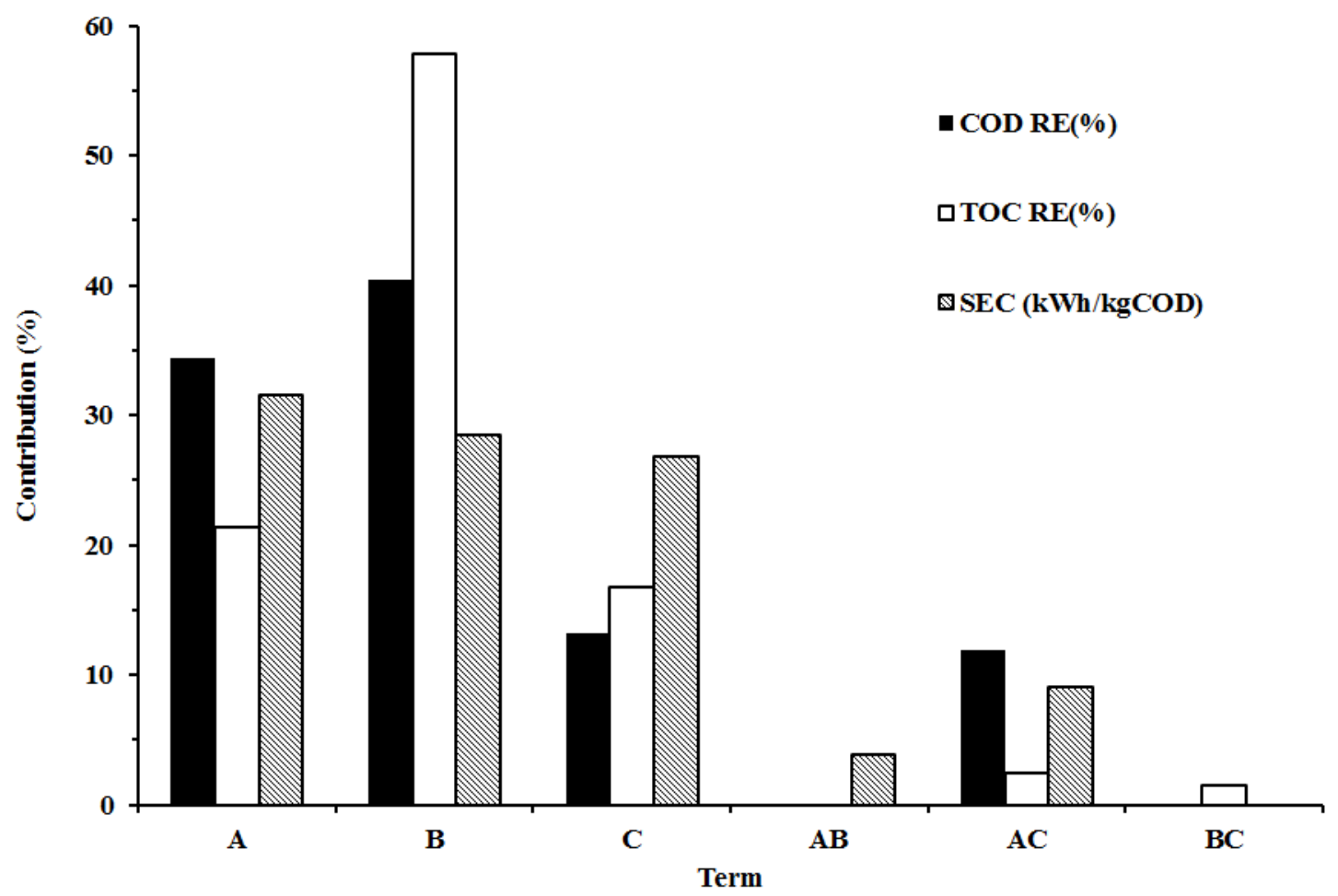

Figure 5. Contribution of all factor (A: Current density, B: Treatment time, C: Electrolyte addition) on the responses. 
Table 1. Characterization of oily wastewater and the performance of electro-oxidation in the optimum operating condition $\left(\mathrm{CD}=23.1 \mathrm{~mA} \mathrm{~cm}^{-2}, \mathrm{t}=120 \mathrm{~min}, \mathrm{~T}=25^{\circ} \mathrm{C}\right)$.

\begin{tabular}{|c|c|c|c|}
\hline Parameters (unit) & Influent & Effluent & Removal (\%) \\
\hline TOC $\left(\mathrm{mg} \mathrm{C} \mathrm{L}^{-1}\right)$ & $378 \pm 12$ & $120 \pm 14$ & $68 \pm 2$ \\
\hline $\mathrm{O} \& \mathrm{G}\left(\mathrm{mg} \mathrm{C} \mathrm{L}^{-1}\right)$ & $43.7 \pm 5$ & ND & 100 \\
\hline $\mathrm{COD}\left(\mathrm{mg} \mathrm{O}_{2} \mathrm{~L}^{-1}\right)$ & $1,160 \pm 215$ & $154 \pm 25$ & $85 \pm 2$ \\
\hline $\mathrm{BOD}\left(\mathrm{mg} \mathrm{O}_{2} \mathrm{~L}^{-1}\right)$ & $98 \pm 15$ & $43 \pm 12$ & $56 \pm 3$ \\
\hline $\mathrm{N}_{\text {tot }}\left(\mathrm{mg} \mathrm{N} \mathrm{L}^{-1}\right)$ & $76 \pm 2$ & $63 \pm 1$ & $18 \pm 3$ \\
\hline $\mathrm{NH}_{4}\left(\mathrm{mg} \mathrm{N} \mathrm{L}^{-1}\right)$ & $54 \pm 1$ & $38 \pm 3$ & $31 \pm 4$ \\
\hline $\mathrm{NO}_{3}\left(\mathrm{mg} \mathrm{N} \mathrm{L}^{-1}\right)$ & $0.4 \pm 0.2$ & $21 \pm 2$ & - \\
\hline $\mathrm{PO}_{4}\left(\mathrm{mg} \mathrm{P} \mathrm{L}^{-1}\right)$ & $0.5 \pm 0.2$ & $0.1 \pm 0.2$ & $80 \pm 10$ \\
\hline $\mathrm{P}_{\text {tot }}\left(\mathrm{mg} \mathrm{P} \mathrm{L} \mathrm{L}^{-1}\right)$ & $1.3 \pm 0.2$ & $0.2 \pm 0.2$ & $75 \pm 20$ \\
\hline $\mathrm{TA}\left(\mathrm{mg} \mathrm{CaCO} \mathrm{CL}^{-1}\right)$ & $695 \pm 15$ & $58 \pm 5$ & $92 \pm 2$ \\
\hline Color (TCU) & $303 \pm 24$ & $23 \pm 3$ & $88 \pm 1$ \\
\hline $\mathrm{EC}\left(\mathrm{ms} \mathrm{cm}^{-1}\right)$ & - & $2.52 \pm 0.24$ & - \\
\hline $\mathrm{pH}$ & $7.12 \pm 0.13$ & 7.31 & - \\
\hline $\mathrm{TS}\left(\mathrm{mg} \mathrm{L}^{-1}\right)$ & $2,750 \pm 110$ & - & - \\
\hline TVS (mg L $\left.{ }^{-1}\right)$ & $835 \pm 20$ & $290 \pm 50$ & $65 \pm 4$ \\
\hline $\mathrm{Al}\left(\mathrm{mg} \mathrm{L}^{-1}\right)$ & $0.2 \pm 0.1$ & $0.09 \pm 0.07$ & $48 \pm 24$ \\
\hline $\mathrm{Ca}\left(\mathrm{mg} \mathrm{L}^{-1}\right)$ & $362 \pm 1$ & $122 \pm 10$ & $66 \pm 3$ \\
\hline $\mathrm{Fe}\left(\mathrm{mg} \mathrm{L}^{-1}\right)$ & $4.3 \pm 0.1$ & $1.2 \pm 0.3$ & $71 \pm 12$ \\
\hline $\mathrm{K}\left(\mathrm{mg} \mathrm{L}^{-1}\right)$ & $78 \pm 1$ & $72 \pm 1$ & $7 \pm 1$ \\
\hline $\operatorname{Mg}\left(\mathrm{mg} \mathrm{L}^{-1}\right)$ & $77 \pm 1$ & $45 \pm 2$ & $41 \pm 2$ \\
\hline $\operatorname{Mn}\left(\mathrm{mg} \mathrm{L}^{-1}\right)$ & $4.8 \pm 0.1$ & $1.0 \pm 0.1$ & $78 \pm 4$ \\
\hline $\mathrm{S}\left(\mathrm{mg} \mathrm{L}^{-1}\right)$ & $97 \pm 1$ & $24 \pm 5$ & $75 \pm 5$ \\
\hline $\mathrm{Cl}\left(\mathrm{mg} \mathrm{L}^{-1}\right)$ & $147 \pm 1$ & $16 \pm 2$ & $89 \pm 11$ \\
\hline $\mathrm{Si}\left(\mathrm{mg} \mathrm{L}^{-1}\right)$ & $5.1 \pm 0.1$ & $4.2 \pm 0.6$ & $19 \pm 14$ \\
\hline $\operatorname{Sr}\left(\mathrm{mg} \mathrm{L}^{-1}\right)$ & $5.9 \pm 0.1$ & $2.9 \pm 1.2$ & $51 \pm 21$ \\
\hline $\mathrm{B}\left(\mathrm{mg} \mathrm{L}^{-1}\right)$ & $0.14 \pm 0.01$ & $0.13 \pm 0.01$ & - \\
\hline
\end{tabular}

TA : total alkalinity, TS : total solid, TVS : total volatile solid 
Table 2. Initial conditions and responses of the electro-oxidation processes for all sets of experiments, including factorial and central composite design.

\begin{tabular}{|c|c|c|c|c|c|c|c|}
\hline \multirow[t]{2}{*}{ Run } & \multicolumn{3}{|c|}{ Factors } & \multicolumn{4}{|c|}{ Responses } \\
\hline & $\begin{array}{c}\text { Current } \\
\text { density } \\
\left(\mathrm{mA} \mathbf{c m}^{-2}\right)\end{array}$ & $\begin{array}{l}\text { Time } \\
(\mathrm{min})\end{array}$ & $\begin{array}{l}\text { Electrolyte } \\
\text { addition }\end{array}$ & $\begin{array}{c}\text { Voltage } \\
\text { (V) }\end{array}$ & $\begin{array}{c}\text { SEC } \\
\left(\mathrm{kWh}^{-1}\right) \\
\left.\mathrm{kg} \mathrm{COD}^{-1}\right)\end{array}$ & $\begin{array}{c}\text { COD } \\
\text { removal } \\
\text { efficiency } \\
(\%)\end{array}$ & $\begin{array}{c}\text { TOC } \\
\text { removal } \\
\text { efficiency } \\
(\%)\end{array}$ \\
\hline 1 & 30.8 & 90 & No & 17.0 & 128.5 & 79.2 & 68.0 \\
\hline 2 & 41.5 & 90 & Yes & 14.2 & 109.4 & 74.7 & 63.5 \\
\hline 3 & 23.1 & 120 & Yes & 11.7 & 82.2 & 60.5 & 47.9 \\
\hline 4 & 23.1 & 60 & Yes & 11.3 & 60.8 & 39.5 & 18.0 \\
\hline 5 & 20.0 & 90 & No & 13.4 & 76.8 & 67.5 & 51.1 \\
\hline 6 & 23.1 & 120 & No & 14.4 & 101.8 & 84.6 & 68.3 \\
\hline 7 & 30.8 & 90 & Yes & 12.5 & 81.2 & 65.5 & 49.5 \\
\hline 8 & 30.8 & 47.6 & Yes & 13.1 & 62.0 & 47.5 & 18.0 \\
\hline 9 & 38.5 & 60 & No & 17.0 & 120.4 & 70.4 & 54.8 \\
\hline 10 & 30.8 & 132.4 & Yes & 13.2 & 101.6 & 81.3 & 70.9 \\
\hline 11 & 38.5 & 60.0 & Yes & 13.7 & 67.8 & 71.7 & 37.3 \\
\hline 12 & 38.5 & 120 & Yes & 13.9 & 113.9 & 86.5 & 78.6 \\
\hline 13 & 30.8 & 90 & No & 17.0 & 131.1 & 77.6 & 66.4 \\
\hline 14 & 30.8 & 90 & No & 17.0 & 131.6 & 77.3 & 64.0 \\
\hline 15 & 30.8 & 90 & Yes & 12.2 & 80.4 & 64.6 & 51.3 \\
\hline 16 & 30.8 & 90 & No & 17.0 & 125.7 & 78.5 & 65.1 \\
\hline 17 & 23.1 & 60 & No & 14.6 & 73.3 & 59.6 & 43.4 \\
\hline 18 & 30.8 & 90 & Yes & 11.7 & 79.0 & 63.0 & 55.0 \\
\hline 19 & 20.0 & 90 & Yes & 11.5 & 62.2 & 50.8 & 32.3 \\
\hline 20 & 38.5 & 120 & No & 16.3 & 182.9 & 88.9 & 81.5 \\
\hline 21 & 30.8 & 90 & Yes & 11.7 & 72.5 & 68.6 & 44.7 \\
\hline 22 & 30.8 & 90 & Yes & 12.9 & 90.2 & 60.8 & 48.9 \\
\hline 23 & 30.8 & 90 & No & 12.9 & 126.8 & 80.2 & 66.7 \\
\hline 24 & 30.8 & 47.6 & No & 16.9 & 89.2 & 59.9 & 47.1 \\
\hline 25 & 30.8 & 132.4 & No & 16.1 & 159.2 & 89.0 & 81.2 \\
\hline 26 & 41.5 & 90 & No & 17.9 & 166.3 & 87.2 & 72.8 \\
\hline
\end{tabular}

